\title{
Scholars and Literati at the Academy of Sciences of Turin (1757-1800)
}

\author{
David de la Croix Chiara Zanardello \\ IRES/LIDAM, UCLouvain
}

This note is a summary description of the set of scholars and literati who were members or associates of the Academy of Sciences of Turin from its inception in 1757 to the eve of the Industrial Revolution (1800).

\section{The ACADEmy}

The second half of the eighteenth century represents an important turning point for Italian intellectual activities, a period when many institutions of learning were established. Among these, the most important one at the national and international level was the Academy of Sciences of Turin; it was also the first to be founded after the 1750s. In 1757, Joseph-Louis Lagrange, Giuseppe Francesco Cigna, and Giuseppe Angelo Saluzzo (Count de Saluces) created the Private Turinese Society, a purely scientific organization, separate from the University of Turin. The development of the society was quick and promising, aided by the publication of the Miscellanea philosophico mathematica Societatis privatae Taurinensis in 1759. Many international scholars started supporting the private society; Euler from Berlin and Haller from Göttingen were among them. Despite the combined effort, the first attempt to upgrade the society into an official Academy dissipated in 1760 . Eventually in 1783, during a favourable period of modernisation, King Victor-Amadeus III of Savoy officially recognized the private organisation as the Royal Academy of Sciences (McClellan 1985). The structure and the motto chosen, Veritas et utilitas, reflected its twofold scope. Members were divided into resident affiliates, whose contributions were mainly directed to the improvement of locals' lives (utilitas), and external affiliates, whose publications were mostly pure scientific documents (veritas). The international success reached by the Turinese Academy was exceptional, only halted when war broke out between the Royal Savoy family and France in 1796. It was not revived until the occupation by Napoleon, in 1801 (McClellan 1985).

\section{SOURCES}

Starting from the list of all historic members in the Dizionario biografico dei Soci dell'Accademia (1973) published by the Turinese Academy, the Academy itself has built an institutional web page summarizing information about approximately 3000 members from its constitution in 1757 until 2020 (at https://www.accademiadellescienze.it/accademia/soci). We mainly used this website, which is continuously updated. Some scholars are still only listed by surname, which makes identification difficult. Additional bibliographic information was found in the digitalized version of the Biografia Medica Piemontese, published in 1824.

\section{SOME STATISTICS}

Table 1 shows some descriptive statistics. There are 356 scholars, and the year of birth is known for most of them (76.1\%). The average age at nomination is 41.1 years, while the mean age at death is older than 68 years. For $75.6 \%$ of these scholars the birthplace is known. The median distance 
between the city of Turin and the location of birth is $244 \mathrm{~km}$, reflecting how attractive the Academy was to international members. The great success of the Academy is demonstrated by the high quality of its members: almost half of the counted scholars have a Wikipedia page written in some language (48\%), and $67.1 \%$ of them have left a footprint in Worldcat, the catalogues of the libraries of the world, either by having published some work, or by having been the subject of published books and articles.

\begin{tabular}{ccccccc}
\hline \multicolumn{2}{c}{ Period } & nb. & \% birth year & mean age & mean age \\
Start & End & obs & known & at appoint. & age \\
at death & at death \\
\hline 1734 & 1800 & 356 & 76.1 & 41.1 & 68.4 & 66.3 \\
\hline \multicolumn{1}{c}{$\begin{array}{c}\text { \% birth place } \\
\text { known }\end{array}$} & $\begin{array}{c}\text { median distance } \\
\text { birth-institution }\end{array}$ & $\begin{array}{c}\text { \% with } \\
\text { Wikipedia }\end{array}$ & $\begin{array}{c}\text { \% with } \\
\text { Worldcat }\end{array}$ \\
\hline 1734 & 1800 & & 75.6 & 244 & 48 & 67.1 \\
\hline
\end{tabular}

Table 1: Summary statistics by period

\section{FIELDS}

Figure 1 shows the relative importance of fields, broadly defined. The great dominance of the fields of science, applied science and medicine reflects the pure scientific character of the original society. Indeed, scholars linked to humanities, law and theology are only $10 \%$ of the total. In addition, there is only one member without any scientific merit, called "honorary".

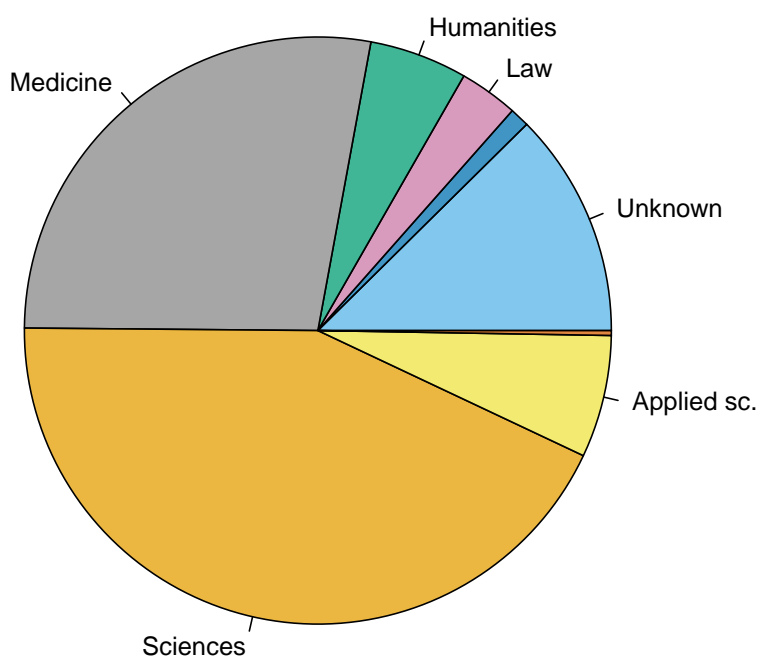

Figure 1: Broad fields at the Academy of Sciences of Turin

\section{Place of Birth}

Figure 2 is a plot of the places of birth of resident and national members of the Academy of Sciences of Turin, while Figure 3 presents only correspondent and foreign affiliated members, as specified by the institutional website of the Academy. This figure shows that through correspondence and external contributions, the Academy was connected with the whole of Europe, with a couple of extra-European links (scholars born in the colonies). However, looking at national and resident members most interactions were concentrated in the North of Italy, especially in the Savoy territories (nowadays, Piedmont) and the South of France, along with Paris. 


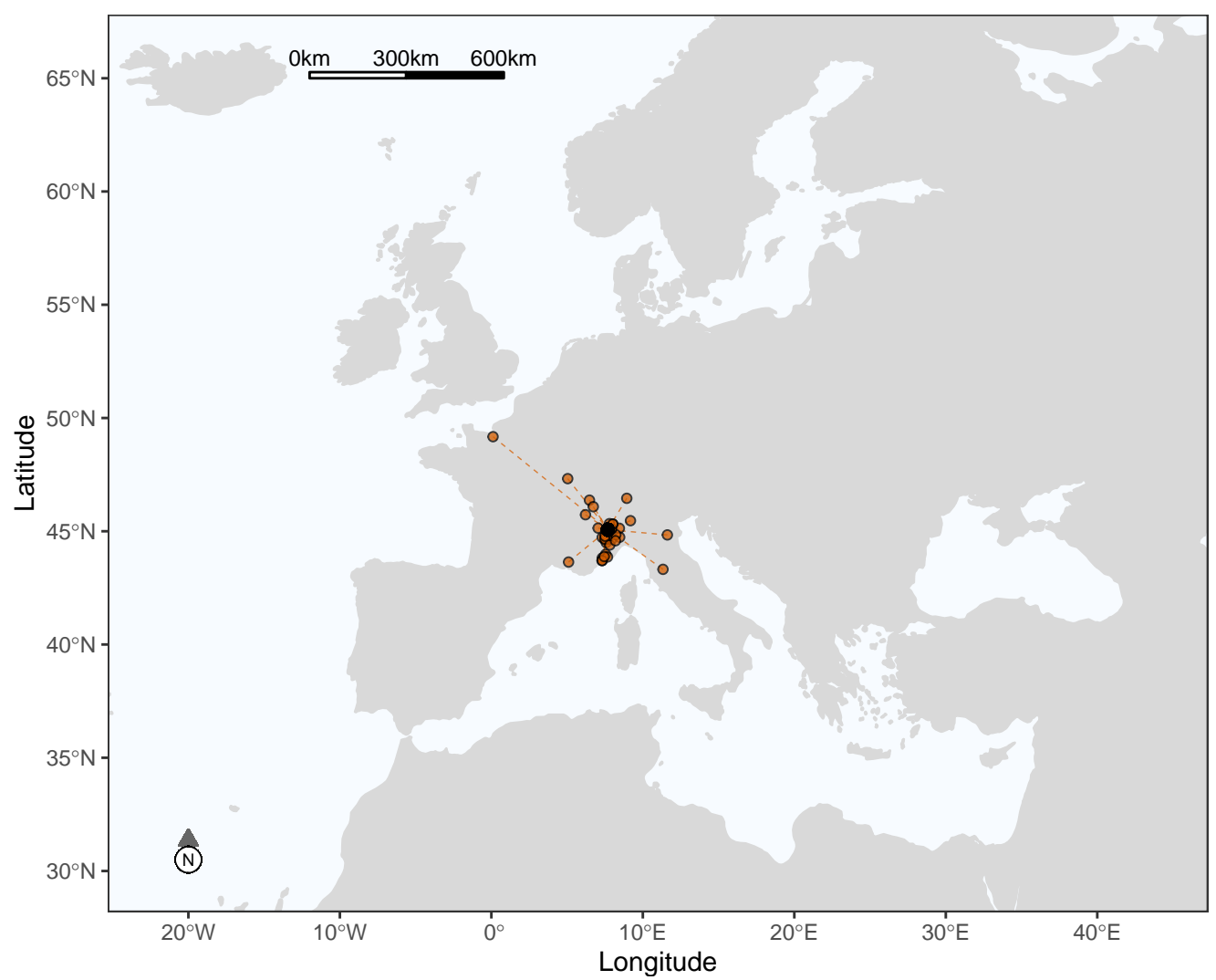

Figure 2: Place of birth of the scholars at the Academy of Sciences of Turin - Ordinary members

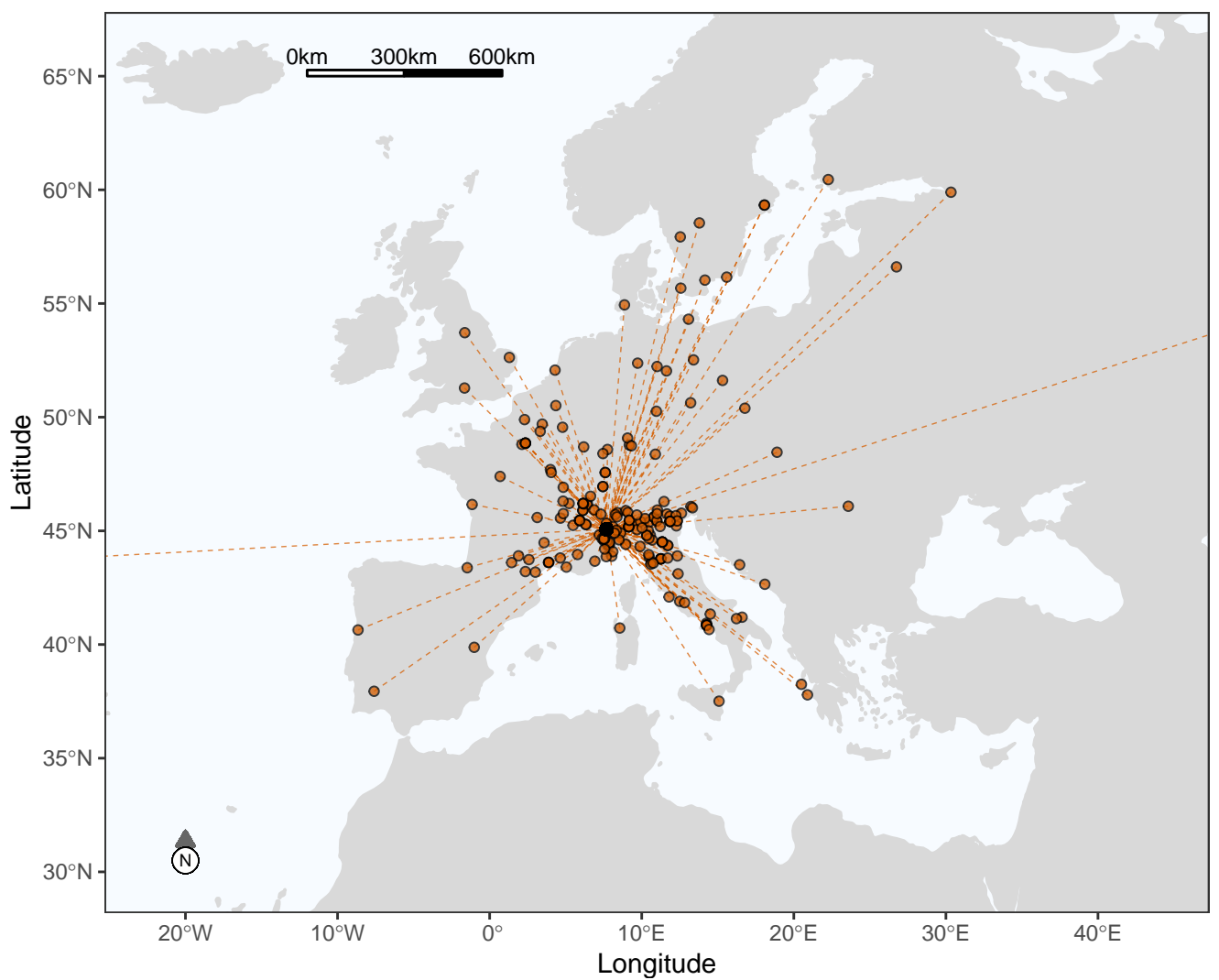

Figure 3: Place of birth of the scholars at the Academy of Sciences of Turin - External members 


\section{HUMAN CAPITAL OF SCHOLARS AND LITERATI}

For each person in the database we compute a heuristic human capital index, identified by combining information from Worldcat and Wikipedia using a principal component analysis. Details are given in the Appendix. Figure 4 shows the names of all the resident and national scholars with a positive human capital index. The vertical green lines (rug plot) show the distribution of all these scholars, including the obscure ones, over time (counting from the beginning of their active life). Figure 4 shows half-a-dozen super stars, and a large portion of resident and national scholars belonging to the mid-high part of the human capital distribution.

\section{TOP 5 SCHOLARS}

We now provide a brief overview of the five resident professors with the highest human capital index.

Pierre-Simon Laplace (Beaumont-en-Auge 1749 - Paris 1827), known also as marquis de Laplace (title gained in 1817), was a French mathematician, engineer, astronomer, and philosopher. He was one of the most important scientists of all time. He was nominated as a member of the Academy of Sciences of Turin in 1766. His work Mécanique celeste (1799 - 1795) was the turning point for mathematical astronomy, defining the shift from a geometric approach to one based on mathematical analysis. Furthermore, he was the main developer of the Bayesian interpretation in probability. In addition to the Academy of Turin, he was also member of the Académie des Sciences in Paris, and of the Académie Française.

Joseph-Louis de Lagrange (Turin 1736 - Paris 1813), was an Italian mathematician and astronomer, also known as Giuseppe Luigi Lagrange. At the age of 21, together with two young friends, Giovanni Francesco Cigna, and the Count de Saluces, he founded the Private Turinese Society. During the Turinese period, he worked on several projects, whose scientific relevance had led to his nomination as a member at the Prussian Academy of Science in Berlin (De la Croix, Eisfeld, and Ganterer 2021). When he was only 30 years old, Lagrange moved to Berlin to fill the position previously occupied by Euler, following a persistent campaign by Frederick II (King of Prussia). He reseigned when the King died, and moved to Paris in 1787, where he was received with great honours. Lagrange was one of the pioneers in probability theory and the calculus of variations, leading to the method based on Lagrangeans and Lagrange multipliers.

Louis-Bernard Guyton de Morveau (Dijon 1737 - Paris 1816) was a French chemist and magistrate. He started his career as a lawyer at the Parliament of Dijon. Louis-Bernard GuytonMorveau turned to Chemistry only in 1764, studying the chemical nomenclature at the Dijon Academy. He was nominated to the Academy of Sciences of Turin in 1783, after having published a study on the chemical nomenclature. In the course of his academic life, he collaborated with other well-known chemists, such as A.L. Lavoisier (1743-1794) and C.L. Berthollet (1748-1822).

Claude Louis Berthollet (Talloires 1748 - Arcueil 1822) was a French chemist and scientist. He graduated from the University of Turin and in 1774 he moved to Paris, where he formed a friendship with A.L. Lavoisier (1743-1794) and L.B. Guyton (1737 - 1816) with whom he published a study on the chemical nomenclature in 1787. In the meantime, he worked in the dye industry, discovering and introducing for the first time a modern commercial bleach. In 1786 he was nominated as a member at the Academy of Sciences of Turin, after determining the chemical formula for the ammonia. 


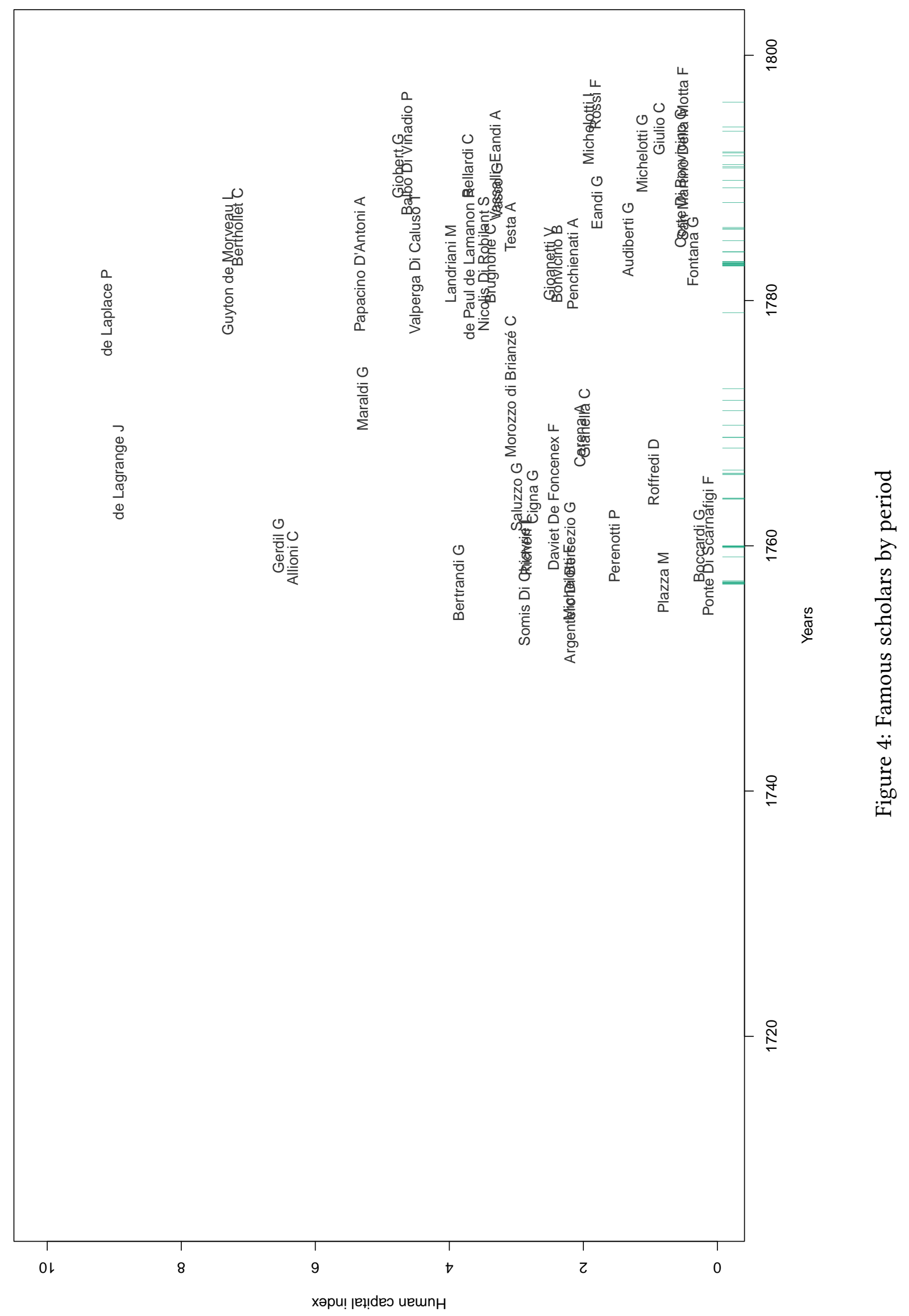


Giacinto Sigismondo Gerdil (Samoëns 1718 - Rome 1802) was an Italian cardinal and a theologian. His birth name was Jean-François, which was changed to Giacinto Sigismondo after his novitiate at the Barnabite order in Annecy. While studying in Bologna, he captured the attention of the future Pope Benedict XIV, Cardinal Prospero Lambertini. He taught at the Barnabite college in Macerata, and during this period he gained success with his writing. In 1760 he was nominated as a member at the Academy of Sciences of Turin. He became Bishop in 1777 and some months later Cardinal, position that allowed him to participate at the Conclave in 1800 . He was not elected Pope because of a veto by the Emperor.

\section{RELATED SCHOLARS}

In addition to the ordinary members residing in Italy, several individuals were linked to the Academy of Turin through a foreign or corresponding membership status. The five scholars shown here belonged to this category. These scholars are included in the calculations for all figures but Figure 4 .

Benjamin Franklin (Boston 1706 -- Philadelphia 1790) was an American writer, inventor, and statesman. He was one of the Founding Fathers of the United States, and of numerous other civic organizations, including the University of Pennsylvania. During the second part of his life, he travelled around Europe, after arriving in London in 1757 and setting up a base there. He also lived in Dublin and Paris, first as a colonial ambassador, and later as a representative of the newly founded American Republic. During this travels he entertained an intense correspondence, mainly about electrology, with Giovanni Battista Beccaria (1716 - 1781), who was the teacher of the three young founders of the Academy of Sciences of Turin. Benjamin Franklin was a foreign member of the Turinese Academy from 1783, the year in which he signed the Treaty of Paris, which ended the American Revolutionary War.

Leonhard Euler (Basel 1707 - Saint Petersburg 1783) was a mathematician at the University of Basel, where he met J. Bernoulli (1700-1782). In 1727 Euler entered the Saint Petersburg Academy of Sciences (for more details see De la Croix and Doraghi (2021)), which he left only in 1741 for the Berlin Academy (i.e. Royal Prussian Academy of Sciences). There, he was the director of mathematical sciences (De la Croix, Eisfeld, and Ganterer 2021). In 1759, he nominated fellow member of the Berlin Academy J.L. Lagrange, who became Euler's successor in 1766. In 1760, Euler became a foreign member of the Academy of Sciences of Turin.

Jean le Rond D’Alembert (Paris 1717 - Paris 1783) was a French mathematician and philosopher. After notable writings and publications, in particular in the field of integral calculus, he entered the Académie des Sciences of Paris when he was not even 25 years old. Three years later, he joined the Berlin Academy as well. He was proposed at the Presidency of this latter Academy by Euler and King Frederick II, but he always refused, preferring a quieter academic life. The exact year of affiliation to the Academy of Sciences of Turin is unknown, but most likely he became an external member in the same period of L. Euler (1707 - 1783), around 1760. In fact, with Euler, Jean le Rond D'Alembert shared the friendship of J.L. Lagrange, a relationship that led to the nomination of Lagrange as the successor of Euler at the Berlin Academy in 1766 .

Nicolas de Condorcet (Ribemont 1743 - Bourg-la-Reine 1794) was a French philosopher, mathematician, and political scientist. From his youth, he was praised by other well-known mathematicians, including J. D’Alembert (1717 - 1783), who later became his teacher. His career was launched in 1765, when his first work on integral calculus appeared. He became a foreign member at the Academy of Sciences of Turin a year later, in the same year as L. Euler (1707 - 1783) and (most likely) as J. D’Alembert (1717 - 1783). In 1769, his works earned him membership of the Académie des Sciences in Paris as well, and in the following years he received honorary memberships from numerous other academies, including in the United States of America. 
Joseph Priestley (Batley, UK 1733 - Northumberland, USA 1804) was an English chemist and philosopher. He had been recognized as a great academic and scientist during his active life, however, his controversial ideas about religion and politics were opposed by many other scholars. He worked on natural philosophy and mathematics, but it is for his writing about the history of electricity that he gained the admiration of influential academics. He met with B. Franklin (1706 - 1790) in London, and this relationship led to Priestley's nomination at the Royal Society of London in 1766. In the following years, he travelled across Europe, pursuing his studies of both science and theology. He published numerous works, and is credited with having discovered oxygen gas. He was nominated as a foreign member of the Academy of Sciences of Turin in 1783 (the same year as B. Franklin). Notwithstanding the great esteem he earned for his academic experience, Joseph Priestley was forced to spend his last years in the United States, when Europe became too dangerous for him, due to his support for the Revolutions that took hold in France and America.

\section{Diversity}

1800 was a year of important changes for the Academy of Sciences of Turin. With the new century, the Academy was divided into two sections: that of the physical, mathematical and natural sciences, and that of the moral, historical and philological sciences. It was also decided to admit women to the academy. The first woman was Diodata Saluzzo (1774-1840), a distinguished poet described by Foscolo as the "Italian Sappho". She was admitted to several literary academies and on 1 January 1801 to the Academy of Sciences of Turin, of which her father was the founder. During the 19th century, eight other women were admitted to this academy, only one of whom was a scientist.

\section{FAMILIES OF SCHOLARS}

Within the Academy of Sciences of Turin, we counted 7 father - son links. Figure 5 shows the Michelotti family. The father, Francesco Domenico, was Professor of Mathematics at the University of Turin from 1754; he was also a resident member of the Academy of Sciences of Turin, but the year of nomination is unknown (most likely, he was nominated at the foundation of the Academy, in 1757). In the "Almanancco reale o sia guida per la città di Torino" (Derossi 1780), there are two Michelotti residing at the same address: Francesco Domenico, and another one without forname - possibly his brother. Francesco Domenico left his position as resident member to his first son, Giuseppe Teresio, in 1784; the son was also Professor of Mathematics at the University of Turin. The other son, Ignazio Maria Lorenzo joined the Turinese Academy in 1791. A third son, Vittorio, was also a professor at the University of Turin and member of the Academy, but not until 1800. All of them were mathematicians and architects, specialised in the construction of the hydraulic systems under the House of Savoy.

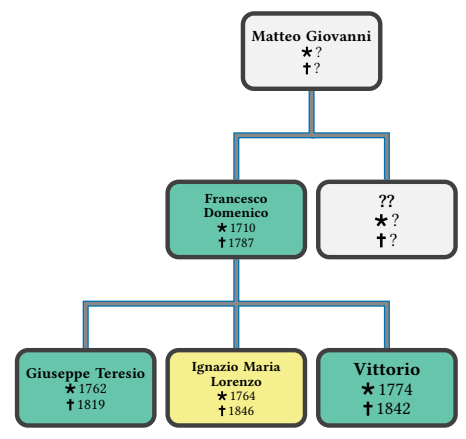

Figure 5: The Michelotti family. Members of both the University of Turin and the Academy of Sciences of Turin in green squares. Members of the Academy of Sciences of Turin (only) in yellow squares. 


\section{ANECDOTES}

The founder of the Academy of Sciences of Turin, Joseph-Louis de Lagrange, changed the style of his name various times before arriving at the well-known "Lagrange". In the first part of his life, he signed with the Italian version of his name "de la Grangia"; translated into French as "de la Grange", but other documents reported the signature "de la Grangia Tournier", or "Tournier de la Grangia" or simply "Tournier". It is only in the second part of his life, when he was living in Paris, that he styled his signature as "Lagrange". Hence, it was only in the last 26 years of his life that he permanently adopted the surname he has been known by ever since.

\section{ApPENDIX}

The individual human capital index $q_{i}$ of an individual $i$ is given by:

$$
\begin{aligned}
q_{i}= & -1.76+0.43 \ln (\mathrm{nb} . \text { of characters of the longest Wikipedia page }) \\
& +0.40 \ln (\mathrm{nb} . \text { of Wikipedia pages in different languages })+0.47 \ln (\mathrm{nb} . \text { of works in Worldcat }) \\
& +0.46 \ln (\mathrm{nb} . \text { of publication languages in Worldcat }) \\
& +0.47 \ln (\mathrm{nb} . \text { of library holdings in Worldcat })
\end{aligned}
$$

We assume that having no Wikipedia page is similar to having one page with a length of 60 characters and that having no Worldcat page is similar to having a page with one work in one language held by one library. The constant -1.76 normalizes $q_{i}$ at 0 when there is neither a Wikipedia page, nor a Worldcat page. The weights $(0.43,0.40$, etc $)$ are obtained from the first principal component of the five indicators (De la Croix et al. 2020).

\section{ACKNOWLEDGMENTS}

This project has received funding from the European Research Council (ERC) under the European Union's Horizon 2020 research and innovation programme under grant agreement No 883033 "Did elite human capital trigger the rise of the West? Insights from a new database of European scholars." We thank Mara Vitale for her help with the Families and Diversity sections.

First version November 28, 2021.

\section{REFERENCES}

Accademia delle Scienze di Torino. 1973. Dizionario biografico dei soci dell'accademia. Torino. https: //www.accademiadellescienze.it/media/1614/download.

Bonino, Giovanni Giacomo. 1824. BiografiaMedica Piemontese. Vol. 2. Bianco.

De la Croix, David, Frédéric Docquier, Alice Fabre, and Robert Stelter. 2020. The Academic Market and the Rise of Universities in Medieval and Early Modern Europe (1000-1800). CEPR Discussion Paper 14509.

De la Croix, David, and Mehrdaad Doraghi. 2021. Scholars and Literati at the Saint Petersburg Academy of Sciences (1724-1800). Repertorium Eruditorum totius Europae 5:17-26. https://doi. org/10.14428/rete.v5i0/Petersburg.

De la Croix, David, Thomas Eisfeld, and Maximilian Ganterer. 2021. Scholars and Literati at the Royal Prussian Academy of Sciences (1700-1800). Repertorium Eruditorum totius Europae 3:19. https://doi.org/10.14428/rete.v3i0/prussian.

Derossi, Onorato. 1780. Almanacco reale o sia guida per la città di torino. Torino, Derossi 1781 (1783): 1786. 
McClellan, James E. 1985. Science Reorganized: Scientific Societies in the Eighteenth Century. New York: Columbia University Press. https://doi.org/10.2307/2739060. 